\title{
Forced lordosis on the thoracolumbar junction can correct double major scoliosis; an innovative approach on brace treatment and etiology of adolescent scoliotic and kyphotic deformities
} Piet JM van Loon*, Bob Kühbauch and Frederik Thunnissen

Address: Dept. of Orthopaedics, Slingeland Ziekenhuis Doetinchem, The Netherlands

* Corresponding author

from $5^{\text {th }}$ International Conference on Conservative Management of Spinal Deformities

Athens, Greece. 3-5 April 2008

Published: 15 January 2009

Scoliosis 2009, 4(Suppl I):O50 doi:I0.I I86/I748-7|6I-4-SI-O50

This abstract is available from: http://www.scoliosisjournal.com/content/4/SI/O50

(C) 2009 van Loon et al; licensee BioMed Central Ltd.

\section{Background context}

Adolescent idiopathic scoliosis is an important spinal deformity. No etiology directed therapy is available. Correction can be achieved with limited options by bracing. The focus of bracing is in the coronal plane and with forces directed at the apices of curves. Bending radiographs in the coronal plane are used to assess flexibility and to predict treatment outcome. The corrective potential of fulcrum lordotic bending in the sagittal plane as technique in bracing has not been addressed in radiographic studies.

\section{Purpose}

To support our hypothesis that an early kyphotic deformity of the thoracolumbar junction plays a role in the development of scoliotic deformities and can be addressed to facilitate correction of scoliosis.

\section{Study design}

A prospective radiographic study was conducted.

\section{Methods}

Anterioposterior spine radiographs of patients with a double major curve pattern scoliosis were obtained in two groups of patients. In group A, radiographs in 3 positions: standing, and supine with and without radiolucent fulcrum $(n=12)$ were taken. In group $B$, radiographs in two positions $(n=28)$ : standing, and supine with lordotic fulcrum were taken. Cobb angles of the scoliotic curves were determined and evaluated statistically. The sagittal con- tour of the thoracolumbar junction in standing position was measured.

\section{Results}

In group A with the patients lying supine, a significant correction of the Cobb angle was obtained at the thoracic level of $15.4 \%$ and the lumbar level of $27.5 \%(\mathrm{p}<0.001)$. Adding in supine position, a lordotic fulcrum on the thoracolumbar junction resulted in further correction at the thoracic level of $15.7 \%$ and lumbar $18.1 \%$ (p < 0.001).

Comparing in group A the thoracic and lumbar curvatures in standing position with that on a lordotic fulcrum in supine position revealed a total reduction of $31 \%$ and $45.6 \%$, respectively. For the independent group $\mathrm{B}$, this reduction in one step is $38 \%$ and $44.4 \%$, respectively.

\section{Conclusion}

In this radiographic study, correction of a double major curve scoliosis in the coronal plane appeared to benefit clearly from the application of a lordotic fulcrum on the thoracolumbar junction. This innovative approach was already valuable in the application of our bracing technique and maybe in developing strategies in surgical correction of scoliosis.

\section{References}

I. Roth M: Idiopathic scoliosis caused by a short spinal cord. Acta Radiol Diagn (Stockh) 1968, 7(3):257-7I.

2. Weiss HR, Negrini S, Rigo M, Kotwicki T, Hawes MC, Grivas TB, et al: Indications for conservative management of scoliosis 
(SOSORT guidelines). Stud Health Technol Inform 2008, 135: 164-70.

3. Rigo M, Negrini S, Weiss HR, Grivas TB, Maruyama T, Kotwicki T: 'SOSORT consensus paper on brace action: TLSO biomechanics of correction (investigating the rationale for force vector selection)'. Scoliosis 2006, I: I I.

Publish with Bio Med Central and every scientist can read your work free of charge

"BioMed Central will be the most significant development for disseminating the results of biomedical research in our lifetime. " Sir Paul Nurse, Cancer Research UK

Your research papers will be:

- available free of charge to the entire biomedical community

- peer reviewed and published immediately upon acceptance

- cited in PubMed and archived on PubMed Central

- yours - you keep the copyright

Submit your manuscript here:

http://www.biomedcentral.com/info/publishing_adv.asp 